in vivo $34: 3723-3730(2020)$

doi:10.21873/invivo.12221

\title{
Classical Drug Digitoxin Inhibits Influenza Cytokine Storm, With Implications for Covid-19 Therapy
}

\author{
BETTE S. POLLARD ${ }^{1 *}$, JORGE C. BLANCO1 ${ }^{2 *}$ and JOHN R. POLLARD ${ }^{3}$ \\ ${ }^{1}$ Silver Pharmaceuticals, Rockville, MD, U.S.A.; \\ ${ }^{2}$ Sigmovir Biosystems, Rockville, MD, U.S.A.; \\ ${ }^{3}$ Department of Neurology, University of Pennsylvania, \\ Philadelphia PA (USA) and Christiana Care Epilepsy Center, Newark, DE, U.S.A.
}

\begin{abstract}
Background/Aim: Influenza viruses, corona viruses and related pneumotropic viruses cause sickness and death partly by inducing cytokine storm, a hyper-proinflammatory host response by immune cells and cytokines in the host airway. Based on our in vivo experience with digitoxin as an inhibitor of $T N F \alpha$-driven $N F_{k} B$ signaling for cytokine expression in prostate cancer in rats and in cystic fibrosis in humans, we hypothesize that this drug will also block a virally-activated cytokine storm. Materials Methods: Digitoxin was administered intraperitoneally to cotton rats, followed by intranasal infection with 107TCID50/100 $\mathrm{g}$ of cotton rat with influenza strain A/Wuhan/H3N2/359/95. Daily digitoxin treatment continued until harvest on day 4 of the experiment. Results: The cardiac glycoside digitoxin significantly and differentially suppressed levels of the cytokines TNF $\alpha$, $G R O / K C, M I P 2, M C P 1$, and IFN $\gamma$, in the cotton rat lung in the presence of influenza virus. Conclusion: Since cytokine storm is a host response, we suggest that digitoxin may have a therapeutic potential not only for influenza and but also for coronavirus infections.
\end{abstract}

Influenza, corona and related pneumotropic viruses cause sickness and death partly by inducing a hyperproinflammatory immune response in the host airway. This immune overreaction, called a cytokine storm, can lead to

This article is freely accessible online.

*These Authors contributed equally to this study.

Correspondence to: Bette S. Pollard, President, Silver Pharmaceuticals, 11008 Lamplighter, Rockville, MD, 20854, U.S.A. Tel: +1 3017989600, e-mail: BettePollard@SilverPharmaceuticals.com

Key Words: Virus, influenza, coronavirus, SARS, COVID-19, RNAvirus, cardiac glycosides, digitoxin, digoxin, ouabain, oleandrin, inflammation, cytokine storm, TNFa, GRO/KC, MIP-2, MCP1, IFN $\gamma$. multiorgan failure and death (1). For example, Influenza A (H5N1) has been shown to activate the TNF $\alpha$-driven NFKB signaling pathway in a mouse host during viral infection, generating a massive overproduction of cytokines, including interleukin 8 (IL-8) and monocyte chemoattractant protein 1 (MCP1), known as cytokine storm (2). As anticipated, inhibitors of $\mathrm{NFkB}$ acutely suppress cytokine storm and increase survival in a mouse model of SARS-CoV infection (3). Recent data show that COVID-19 also activates NFKB (4). Cytokine storm marks the airways of SARS-CoV-2infected patients that were admitted to the Intensive Care Unit (ICU) with more severe disease (5). Since there are multiple strains of influenza as well as coronavirus, there might be an advantage to develop therapies that suppress host-induced cytokine storm, in addition to developing strain-specific vaccines.

The clinical problem is that there are limited options for treating respiratory cytokine storm, most of which are predicated on inhibiting $\mathrm{NFKB}$-activated cytokine expression (6-8). The absence of NFKB inhibitory drugs from the human formulary is due to most candidate drugs being either neurotoxic or nephrotoxic when administered chronically (9). One drug that lacks these toxicities is the cardiac glycoside digitoxin. We have previously shown digitoxin to be amongst the most potent inhibitors of the proinflammatory TNF $\alpha /$ NFkB pathway in the human airway and in other epithelial cells, both in vitro (10) and in vivo (11-13). Corroborating this discovery is a screen of 2800 drugs and bioactive compounds which found digitoxin to be one of the most potent inhibitors of TNF $\alpha$-driven-NFkB activity (14). Digitoxin is a drug that has been used to treat heart failure for decades, and a clinical trial (11) demonstrated that in addition to giving it to people with heart failure or heart arrythmias, it is also safe to give digitoxin for diseases like cystic fibrosis to children and adults with normal hearts who need to have reduction of lung inflammation (15). Digitoxin was also recently shown to block MERS-CoV infectivity in 
vitro (16). The digitoxin analogues digoxin and ouabain also block SARS-CoV-2 infectivity in vitro (17). In a clinical trial where digitoxin was administered to young adults with the proinflammatory lung disease cystic fibrosis, it proved safe. This clinical trial also showed that "the mRNAs encoding chemokine/cytokine or cell surface receptors in immune cells were decreased in nasal epithelial cells, leading to pathway-mediated reductions in IL-8 and IL-6 levels, lung epithelial inflammation, neutrophil recruitment and mucus hypersecretion" (11).

To further test the ability of digitoxin to inhibit cytokine storm in related pneumotropic viruses, we used the cotton rat model of influenza infection to investigate the effects of digitoxin in influenza-associated cytokine storm. The cotton rat model has the important advantage of susceptibility to influenza infection without engineered adaptation (18). Based on mRNA changes in an experiment from the same laboratory that we used, when the cotton rats were given only the influenza A H3N2 virus but no drug, the cytokine levels were shown to increase in the cotton rat lung from baseline 10-fold for tumor necrosis factor alpha (TNF $\alpha$ ), 40-fold for interferon gamma (IFN $\gamma$ ), 10-fold for growth-regulated oncogene/ keratinocyte chemoattractant $(\mathrm{GRO} / \mathrm{KC})$, and 35-fold for macrophage inflammatory protein-2 beta (MIP1 $\beta$ ) (19). Consistently, there is a close relationship between mRNA and protein changes for cytokine proteins (20). In addition, it has also been shown in vivo that in the presence of lipopolysaccharides (LPS), GRO/KC and MIP2 mRNAs increase 50-fold and 20-fold, respectively (21). Thus, cytokine levels in the absence of virus or other immune stimulant in the cotton rat lung are very low. Furthermore, it has been shown that the cytokine response of the cotton rat to this virus strain evokes a pattern of pulmonary cytokine changes that parallel the human response (19).

\section{Materials and Methods}

Animal protocol. Cotton rat experiments were performed as previously described (19). All experiments were performed using protocols that followed federal guidelines and were approved by the Institutional Animal Care and Use Committee. Animals were sacrificed by carbon dioxide inhalation.

Drugs and protocol for drug preparation. Digitoxin was obtained from Sigma-Aldrich (> 95\% pure) (St. Louis, MO, USA). The drug was prepared as a stock solution in $95 \%$ ethanol. It was diluted into phosphate buffered saline (PBS) as the suspension solution from the stock solution. It was administered in a $200 \mu \mathrm{l}$ volume. Digitoxin $(0,3,10$ and $30 \mu \mathrm{g}$ per $100 \mathrm{~g}$ of body weight) was administered to 3 cotton rats in one dose intraperitoneally $6.25 \mathrm{~h}$ before intranasal infection with 107TCID50/100 g of cotton rat with influenza strain A/Wuhan/H3N2/359/95. This ensured drug availability at the time of virus infection, as distribution is complete within 4 to $6 \mathrm{~h}$ (22). Daily digitoxin treatment continued until harvest on day 4 of the experiment.
Tissue preparation and histological analysis. On day 4 post infection the animals were sacrificed by $\mathrm{CO}_{2}$ inhalation. The left lung was first tied off and reserved for cytokine analysis. These lung samples were then immediately frozen on dry ice, and kept at $-80^{\circ} \mathrm{C}$ until further processed. The remaining lung tissue was processed for histological analysis. The right lung was inflated with $70 \%$ formalin and fixed for histology, as previously described (19). The frozen left lungs were then transferred to author BSP.

Later, sections were stained by Hematoxylin and Eosin (H\&E) and immune cell density was automatically analyzed in brightfield mode on a Zeiss Axio-Scan.Z1 digital slide scanner (Carl Zeiss AG, Oberkochen, Germany). Whole lung images (2 sections from each lung) were analyzed using NIH-ImageJ. Briefly, the program was trained to identify immune cells as dark stained objects in the section that were the size of neutrophils. The per cent total area occupied by such objects was measured.

Biochemical analysis. Frozen lung samples were weighed, thawed and minced with scissors in 10\% (w/v) ice cold PBS, homogenized with 10 strokes of a Ten Broeck homogenizer (Vavantor, Radnor, PA, USA), and centrifuged at $20,000 \times g$ for $30 \mathrm{~min}$. The supernatant solutions were kept at $-80^{\circ} \mathrm{C}$ until assay. The supernatant solutions were brought to Bioassay Works (LLC, Ijamsville, MD, USA) by author BSP where they were tested for cytokines and chemokines by ELISA. The samples were then sent for corroboration to Pierce-Thermo (Waltham, MA, USA) for ELISA assay on the Searchlight ${ }^{\circledR}$ ELISA platform. Rat antibody reagents were used in both instances.

Statistics. All data are presented as means \pm SEM from three animals for each digitoxin dose. The mean values for each cytokine were analyzed using one-way ANOVA followed by Dunnett's posthoc comparisons of each dose of digitoxin $v s$. vehicle $(0 \mu \mathrm{g})$. Differences were considered significant when $p<0.05$. Complete statistical data are summarized in Table I. The same method was used to compute the significance of histology-based differences between immune cell density at each dose of digitoxin $v s$. vehicle $(0 \mu \mathrm{g})$ in Table II.

\section{Results}

Digitoxin blocks cytokine storm. As shown in Figure 1, protein data were collected for IFN $\gamma, \mathrm{GRO} / \mathrm{KC}$ as the rodent equivalent of human IL-8, MIP2, chemokine (C-X-C motif) ligand 2 (CXCL2), TNF $\alpha$, IL-1 $\beta, \mathrm{MCP} 1$, and transforming growth factor beta (TGF $\beta$ ). Figure 1 also shows the changes in cytokine protein in the lung due to digitoxin administration in the cotton rat following intranasal (IN) infection with a dose of $107 \mathrm{TCID} 50 / 100 \mathrm{~g}$ of animal with influenza strain A/Wuhan/H3N2/359/95 virus. Animals were given three different doses of digitoxin, starting $6.25 \mathrm{~h}$ prior to virus administration and continuing with a daily dose until sacrifice on day 4 . The dose range of digitoxin, $0-30 \mu \mathrm{g} / 100 \mathrm{~g}$ cotton rat, was calculated (23) to approximate the human dose routinely used to treat heart failure $(0.1 \mathrm{mg}$ digitoxin, Merck KGaA, Darmstadt, Germany). As shown in Figure 1 and summarized in Table I, significant digitoxin-dependent reductions were found at $>10 \mu \mathrm{g}$ doses for 5 of the 7 cytokines. The digitoxin- 
Table I. Reduction of cytokine expression by digitoxin in cotton rat lungs.

\begin{tabular}{|c|c|c|c|c|c|c|c|c|}
\hline \multirow{2}{*}{$\begin{array}{l}\text { Cytokine } \\
\text { IFN } \gamma\end{array}$} & \multirow{2}{*}{$\begin{array}{c}\begin{array}{c}\text { Digitoxin } \\
\text { Dose, } \mu \mathrm{g} / 100 \mathrm{~g}\end{array} \\
0\end{array}$} & \multirow{2}{*}{$\begin{array}{l}\mathrm{N} \\
3\end{array}$} & \multicolumn{3}{|c|}{$\begin{array}{l}\text { Cytokine Concentrations, } \\
\mathrm{pg} / \mathrm{ml}\end{array}$} & \multirow{2}{*}{$\begin{array}{l}\text { Mean } \\
\mathbf{3 4 . 7 7}\end{array}$} & \multirow{2}{*}{$\begin{array}{c}\begin{array}{c}\text { Std. } \\
\text { Deviation }\end{array} \\
\mathbf{4 . 9 3}\end{array}$} & \multirow[t]{2}{*}{$\begin{array}{c}p \text {-Value } \\
\text { (Dunnett's) }\end{array}$} \\
\hline & & & 29.1 & 37.1 & 38.1 & & & \\
\hline & 3 & 3 & 13.7 & 25.0 & 34.6 & 24.43 & 10.46 & 0.159 \\
\hline & 10 & 3 & 12.5 & 12.5 & 15.5 & 13.50 & 1.73 & 0.007 \\
\hline & 30 & 3 & 7.3 & 12.5 & 12.5 & 10.77 & 3.00 & 0.003 \\
\hline \multirow[t]{4}{*}{$\mathrm{GRO} / \mathrm{KC}$} & 0 & 3 & 22.0 & 29.2 & 32.4 & 27.87 & 5.33 & \\
\hline & 3 & 3 & 18.4 & 23.4 & 24.7 & 22.17 & 3.88 & 0.238 \\
\hline & 10 & 3 & 8.9 & 14.6 & 16.1 & 13.20 & 3.80 & 0.004 \\
\hline & 30 & 3 & 12.2 & 16.0 & 16.4 & 14.87 & 2.32 & 0.008 \\
\hline \multirow[t]{4}{*}{ MIP2 } & 0 & 3 & 15.6 & 15.6 & 17.6 & 15.83 & 0.40 & \\
\hline & 3 & 3 & 12.4 & 14.1 & 15.5 & 14.00 & 1.55 & 0.421 \\
\hline & 10 & 3 & 7.1 & 7.8 & 12.3 & 9.07 & 2.82 & 0.002 \\
\hline & 30 & 3 & 10.6 & 10.7 & 10.9 & 10.73 & 0.15 & 0.012 \\
\hline \multirow[t]{4}{*}{$\mathrm{TNF} \alpha$} & 0 & 3 & 74.6 & 76.5 & 80.9 & 77.33 & 3.23 & \\
\hline & 3 & 3 & 62.4 & 75.4 & 79.4 & 72.40 & 8.89 & 0.899 \\
\hline & 10 & 3 & 28.2 & 33.4 & 54.9 & 38.83 & 14.15 & 0.006 \\
\hline & 30 & 3 & 35.6 & 44.9 & 62.3 & 47.60 & 13.55 & 0.025 \\
\hline \multirow[t]{4}{*}{ IL1 $\beta$} & 0 & 3 & 194.0 & 285.8 & 324.0 & 267.93 & 66.82 & \\
\hline & 3 & 3 & 106.7 & 224.4 & 239.3 & 190.13 & 72.64 & 0.534 \\
\hline & 10 & 3 & 123.6 & 317.7 & 332.7 & 258.00 & 116.64 & 0.997 \\
\hline & 30 & 3 & 125.2 & 203.5 & 226.2 & 184.97 & 52.99 & 0.489 \\
\hline \multirow[t]{4}{*}{$\mathrm{MCP} 1$} & 0 & 3 & 4.5 & 8.1 & 8.8 & 7.13 & 2.31 & \\
\hline & 3 & 3 & 2.2 & 2.6 & 5.4 & 3.40 & 1.74 & 0.049 \\
\hline & 10 & 3 & 1.6 & 1.6 & 1.6 & 1.60 & 0.00 & 0.007 \\
\hline & 30 & 3 & 1.9 & 3.4 & 4.4 & 3.23 & 1.26 & 0.040 \\
\hline \multirow[t]{4}{*}{ TGF $\beta$} & 0 & 3 & $1,167.1$ & $1,192.5$ & $1,192.5$ & $1,184.07$ & 14.61 & \\
\hline & 3 & 3 & 901.3 & $1,029.9$ & $1,079.9$ & $1,003.70$ & 92.14 & 0.350 \\
\hline & 10 & 3 & 806.1 & $1,095.2$ & $1,122.1$ & $1,007.80$ & 175.19 & 0.366 \\
\hline & 30 & 3 & 969.9 & $1,041.1$ & 1364.0 & $1,125.00$ & 210.02 & 0.923 \\
\hline
\end{tabular}

Bold $p$-Values indicate statistical significance.

dependent reductions were specific and saturating for each cytokine, but did not reduce any of them to zero.

Digitoxin differentially affects cytokine expression. Table I shows that the most significant digitoxin-dependent reductions of cytokine proteins were found in IFN $\gamma(68.9 \%)$, GRO/KC (46.6\%), and MCP1 (54.9\%). Smaller but still significant reductions in cytokine proteins were found in MIP2 (32.2\%) and TNF $\alpha$ (38.4\%). In the cases of IL-1 $\beta$ and TGF $\beta$ changes were not significant. Taken together, digitoxin, dose-dependently and significantly lowers the individual concentrations in the lung of at least five cytokines that had been induced by viral infection.

Digitoxin leaves immune cell density intact in virus-infected lung. Figure $2 \mathrm{a}$ and Figure $2 \mathrm{~b}$ show low-power views of cotton rat lung sections, taken 4 days after intranasal virus administration (no digitoxin and $10 \mu \mathrm{g}$ digitoxin/100 g, respectively). Changes in cytokines appear to saturate at a dose of $10 \mu \mathrm{g} / 100 \mathrm{~g}$ cotton rat. Regions of heavy hematoxylin staining, representing infiltration foci of
Table II. Effect of digitoxin on immune cell density in cotton rats treated with influenza virus strain A/Wuhan/H3N2(359/95)*.

\begin{tabular}{lccc}
\hline $\begin{array}{l}\text { Digitoxin dose, } \\
\mu \mathrm{g} / 100 \mathrm{~g} \text { Cotton Rat }\end{array}$ & $\begin{array}{c}\text { Total positive area } \\
(\mathrm{Sq} \mu \mathrm{m})\end{array}$ & $\begin{array}{c}\% \text { Positive } \\
\text { area }\end{array}$ & $\begin{array}{c}p \text {-Value } \\
\text { (Dunnett's) }\end{array}$ \\
\hline $0(\mathrm{n}=6)$ & $251,575,564.80$ & 8.59 & - \\
$3(\mathrm{n}=6)$ & $138,565,605.10$ & 7.72 & 0.764 \\
$10(\mathrm{n}=6)$ & $132,292,021.0$ & 9.54 & 0.716 \\
$30(\mathrm{n}=5)$ & $132,292,021.10$ & 10.02 & 0.481 \\
\hline
\end{tabular}

*Two sections from each of 3 Cotton Rat lungs were analyzed. One of the 2 sections from one lung treated with $30 \mu \mathrm{g} / 100 \mathrm{~g}$ digitoxin was damaged.

immune cells, are distributed in the lung. As previously described, pulmonary inflammatory changes can be seen in terms of peribronchitis (inflammatory cells clustered around the periphery of small airways), interstitial pneumonia (inflammatory cell infiltration and thickening of alveolar walls) and alveolitis (immune cells within the alveolar spaces) $(19,24)$. 

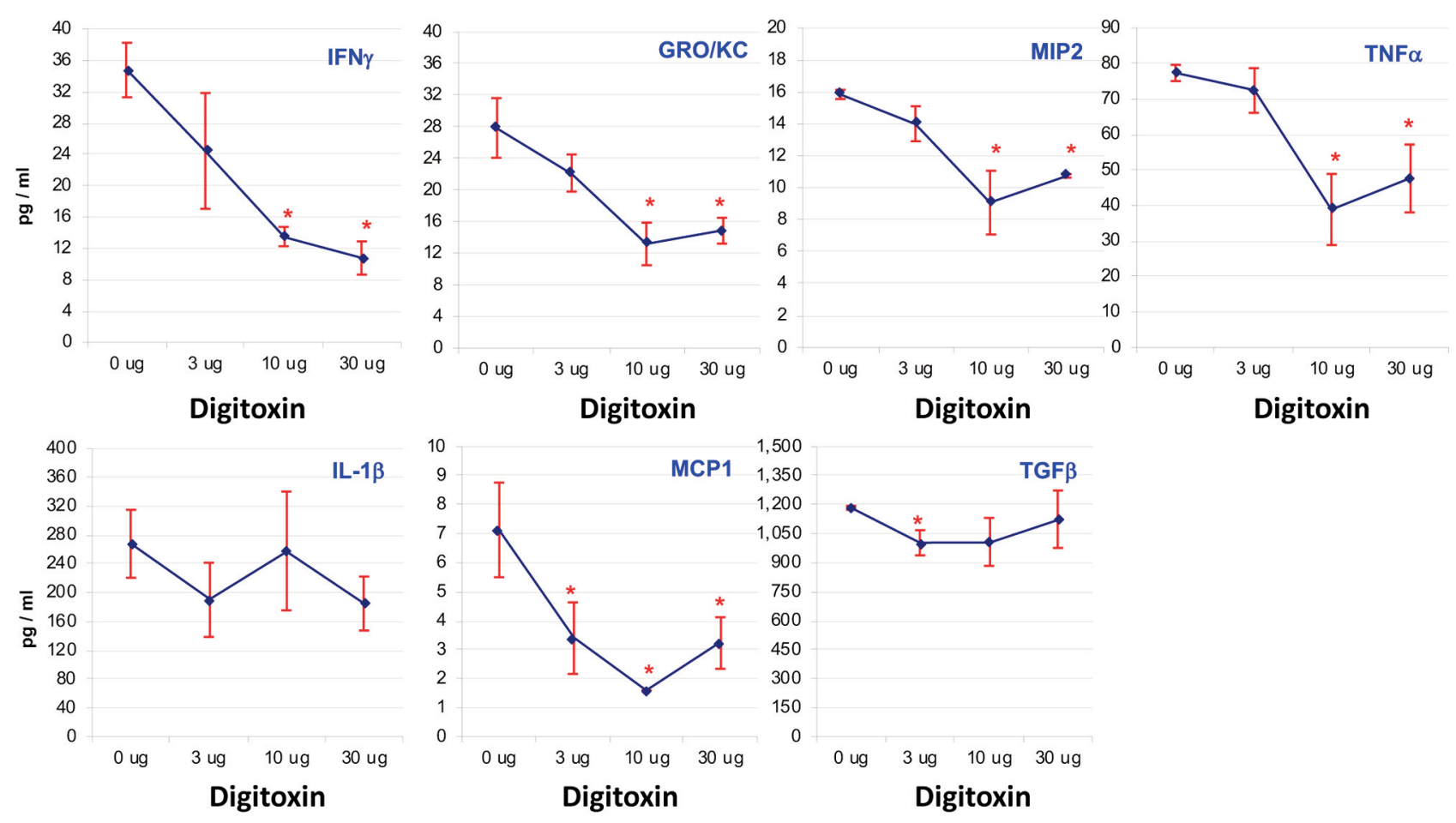

Figure 1. Cytokine concentrations in lungs of cotton rats treated with digitoxin and influenza strain A/Wuhan/H3N2/359/95 virus. Animals were treated with different concentrations of digitoxin 6.25 hours before intranasal virus administration and daily thereafter for 4 days. Samples assayed were lung tissue. Digitoxin dose is in units of $\mu \mathrm{g} / 100 \mathrm{~g}$. IFN $\gamma$ : Interferon gamma; GRO/KC: growth-regulated oncogenel keratinocyte chemoattractant; MIP2: macrophage inflammatory protein-2 ; CXCL2: chemokine (C-X-C motif) ligand 2; TNF $\alpha$ : tumor necrosis factor alpha; IL1 $\beta$ : interleukin 1 beta; MCP1: monocyte chemoattractant Protein 1 (or CCL2); TGF $\beta$ : transforming growth factor beta. * $p<0.05$, N=3.

Densities of immune cells were not affected by digitoxin. Table II shows that the positive area (\%) occupied by immune cells in treated animals was not statistically different from the area occupied by immune cells in untreated, virus-infected animals. Thus, digitoxin appears to inhibit the cytokine storm host response to influenza A infection but does not significantly affect the density and distribution of immune cells as seen in the microscope on the 4th-day after infection.

\section{Discussion}

Our experimental results in Figure 1 and Table 1 show that administration of digitoxin to the cotton rat inhibits expression of five cytokines in the lung in the presence of influenza strain A/Wuhan/H3N2/359/95. These cytokines include TNF $\alpha$, the key activator of the TNF $\alpha$-driven NFKB inflammation pathway. The data also show that digitoxin inhibits cytokine storm, but does not appear to significantly affect the density of immune cells in the lung four days after viral infection. The data further suggest that digitoxin acts on multiple cell types (25). For example, IFN $\gamma$ is secreted only from activated $\mathrm{T}$ lymphocytes and NK cells of the immune system 5). The remainder of the cytokines are secreted by epithelial cells in the airway, as well as by endothelial cells, immune cells and others $(26,27)$. GRO/KC [CXCL1, the rodent equivalent of human IL-8 (28)], and MIP2 are a key target of NFKB signaling and are major chemoattractants for neutrophils (29). MIP1 induces entry and accumulation of monocytes and macrophages into the lung, and are targets of NFKB (29). TGF $\beta$ is indirectly dependent on NFKB-signaling and indirectly drives $\mathrm{NFkB}$ (12). IL-1 $\beta$ also drives NFkB, albeit not through TNF $\alpha$. The data from Figure 1 and Table I support the interpretation that digitoxin-dependent reduction in $\mathrm{TNF} \alpha$-driven $\mathrm{NFKB}$ signaling may be sufficient to suppress influenza Aassociated cytokine storm.

The reduction of influenza A-driven TNF $\alpha$ expression by digitoxin is specifically relevant to what is known regarding the mechanism of influenza A virus RNA production and propagation (30). For example, TNF $\alpha$ drives $\mathrm{NFkB}$ activation and signaling by host $\mathrm{NFKB}$, which has been shown to be a prerequisite for influenza virus infection (3032). Knockdown of host NFkB_p65 has also been found to reduce influenza virus replication and vRNA synthesis (30). 

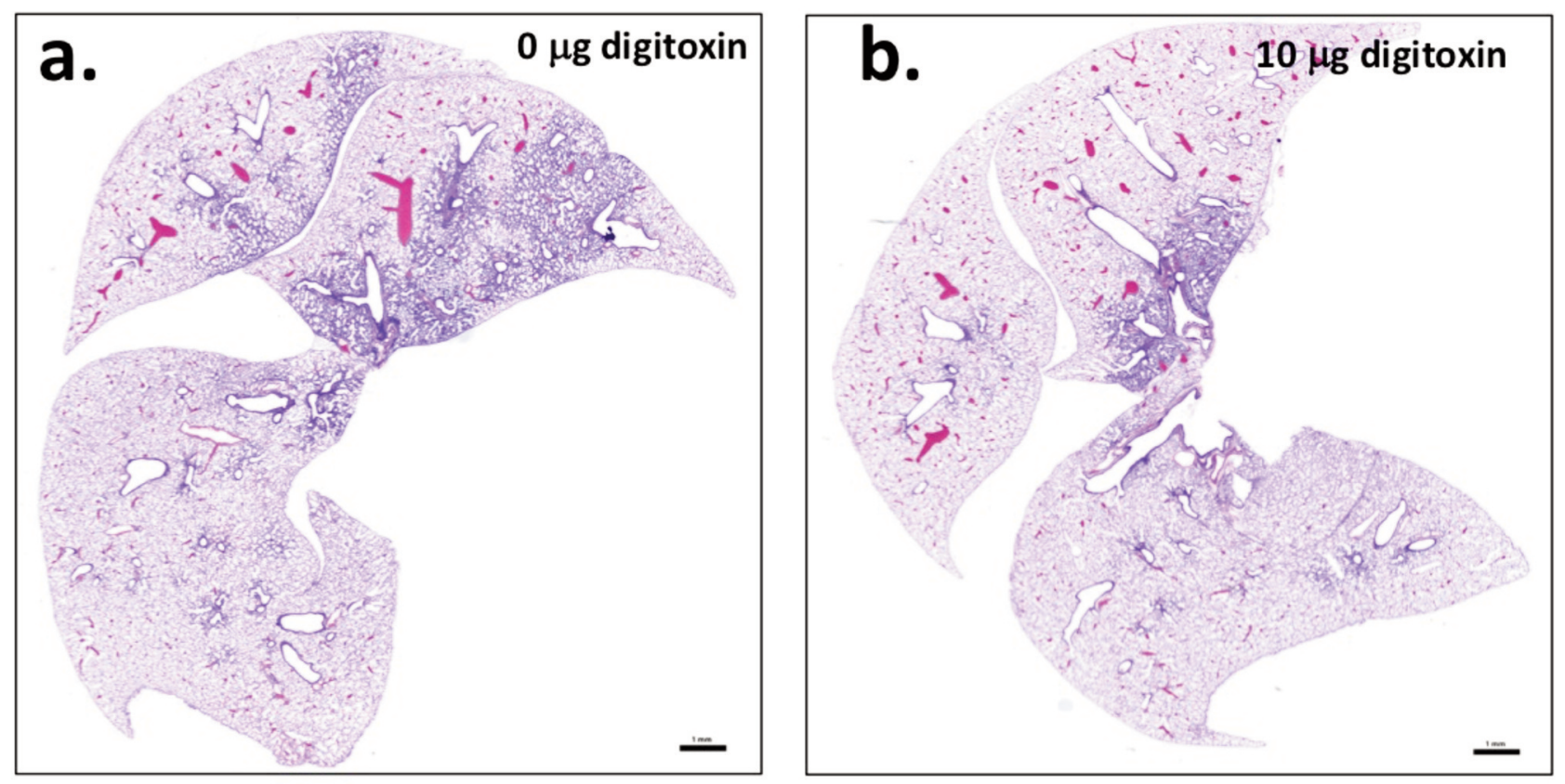

Figure 2. Histology of cotton rat lungs following infection with influenza strain A/Wuhan/H3N2/359/95 and treatment for 4 days with digitoxin. (a) Low power image of infected, control cotton rat lung (magnification 10x). (b) Low power image of infected cotton rat lung treated with $10 \mu \mathrm{g} / 100 \mathrm{~g}$ digitoxin for 4 days. Analysis shows that the density of immune cells, marked by the NIH ImageJ program, is not statistically different when comparing all treatment conditions from control (also see Table II). Scale bar=1 $\mathrm{mm}$.

This relationship appears to be dependent on viral genes because mouse-adapted descendants of the avian Influenza A strain $\mathrm{H} 7 \mathrm{~N} 7$ can be genetically engineered to function independently of NFkB, using CRISPR-Cas9 editing (33). More recently, it was shown that cirsimaritin, a pure flavonoid from Chinese medicine, blocks NFkB signaling induced in MDCK and THP-1 cells by influenza A strains $\mathrm{H} 1 \mathrm{~N} 1$ and $\mathrm{H} 3 \mathrm{~N} 2$, and suppresses virally activated expression of TNF $\alpha$, IL-8 and other cytokines (34). In prospect, our present work shows that digitoxin, a specific blocker of TNF $\alpha$-driven NFKB signaling, achieves an analogous result in vivo with influenza A strain $\mathrm{H} 3 \mathrm{~N} 2$.

The decision to analyze the response to digitoxin on the 4th day after infection was based on the observation that in the cotton rat lung, mRNA expression for many cytokines reaches maximal level on that day in response to A/Wuhan/H3N2/359/95 infection (19). Our data show that digitoxin treatment causes the most profound reduction in INF $\gamma$ expression relative to the other cytokines. The potential importance of digitoxin-dependent INF $\gamma$ reduction may be manifest by a recent report, where simply neutralizing INF $\gamma$ in a mouse model of infection with influenza A virus strain A/California/07/2009 (H1N1v; "Swine Flu") was sufficient not only to alleviate acute lung injury but also to increase weight and survival rate (35). Why digitoxin is so powerful a suppressor of INF $\gamma$ is not immediately obvious. However, it is known that IFN $\gamma$ expression is driven by a combination of both NFKB and NFAT acting on the IFN $\gamma$ promoter (36). We have previously reported that digitoxin not only reduces NFkB, but also reduces NFAT expression (37). It is, therefore, possible that the suppression of both of these transcription factors may contribute to digitoxin's potent suppression of virally-induced INF $\gamma$ expression.

Influenza $A$ is known to drive activation of IL-1 $\beta$ and TGF $\beta$, but in these experiments digitoxin did not significantly change the expression of these cytokines, as it did to the others. The importance of IL- $1 \beta$ for influenza $A$ is that it is synthesized by alveolar macrophages and dendritic cells in response to viral infection (38). Its role is to drive neutrophilic inflammation in a manner unrelated to the levels of GRO/KC or MIP-2 $\alpha$ in the virus-infected mouse lung (39). We conclude that further understanding of this complexity will depend on additional investigation. TGF $\beta$ expression is also driven by influenza A in response to viral infection (40); however, the regulation of TGF $\beta$ expression itself remains poorly understood, and is also not directly dependent on NFKB (12). It is possible that the difference may lie in the fact that digitoxin acts directly on the TNF $\alpha$-driven NFkB pathway, but that IL- $1 \beta$ and TGF $\beta$ act on NFkB indirectly or by alternative pathways. For example, digitoxin acts directly to suppress 
TNF $\alpha$-driven NFKB signaling by blocking the binding of the TNF $\alpha /$ TNFR1 to TRADD $(41,42)$. Tumor necrosis factor receptor type 1-associated death domain (TRADD) is the first intracellular adaptor for the TNF $\alpha / T N F R 1$ complex, and the resulting ternary complex directly drives the downstream activation of IKK $\alpha, \beta, \& \gamma$, phosphorylation of $\operatorname{IkB} \alpha$, and, thus, activation of $\mathrm{NFkB}$. Increased cytokine expression follows NFKB activation.

Finally, it is a limitation of this study that there may be antiviral effects of digitoxin that may contribute to reduction in host-driven cytokine storm, and may also have implications for COVID-19 therapy. This is because digitoxin and the other approved cardiac glycosides, digoxin and ouabain have been shown to have inhibitory properties for coronaviruses and other viruses (43). With respect to COVID-19, digoxin and ouabain have been shown to block cell penetration and infectivity when tested against SARS-CoV-2 (17). Furthermore, digitoxin itself has been shown to block Middle East respiratory syndrome, MERS $\mathrm{CoV}$ penetration into target cells and subsequent infectivity (16). Previously, digoxin was shown to block MERS-CoV penetration and infectivity (44). In silico molecular docking analysis based on CRYO-EM structures has shown that digitoxin, out of 15,000 molecular candidates, binds best to the receptor binding domain (RBD) of the SARS-CoV2 Spike (45). A similar study by others has come to the same conclusion (46). Both the latter authors suggested that digitoxin may block the interaction of SARS-CoV-2 with the receptor ACE2. Using the same in silico screening approach, but also followed by an in-vitro test, ouabain was shown to dock optimally to the SARS-CoV-2 Main protease (Mpro), and to block viral penetration and infectivity (47). Consistently, digitoxigenin, a digitoxin without the three sugars at the $3{ }^{\prime} \mathrm{OH}$ position, has also been shown to dock optimally to the Mpro (48). With respect to the activation of the cytokine storm, we have already noted that $\mathrm{TNF} \alpha$-driven NFKB activation by the host drives cytokine storm for Influenza A (2), for SARS-CoV (3), and for SARS-CoV-2 (4). Consistently, digitoxin potently blocks this host-response process, independent of viral activation, at low $\mathrm{nM}$ concentrations $(10,11,13,37,41)$. Since the cardiac glycosides digitoxin, digoxin and ouabain are approved drugs, we conjecture that the suppressive effects of digitoxin on influenza A cytokine storm shown here could be quite relevant to future tests of cardiac glycoside-based therapies for COVID-19.

In conclusion, these data show that digitoxin blocks the host over-production of cytokines raised by influenza strain A/Wuhan/H3N2/359/95 in the cotton rat lung. Since digitoxin has already been shown to be safe in an FDA Phase II clinical trial with cystic fibrosis patients with pulmonary disease and a normal heart, and has been shown to cause a similar reduction in NFkB driven cytokine expression, this drug may be a good candidate for further investigation as a therapy for influenza and potentially for COVID-19.

\section{Conflicts of Interest}

Bette Pollard has a patent on anti-inflammatory and immune properties of cardiac glycosides, such as digitoxin and its use in treatment of diseases.

\section{Authors' Contributions}

BSP requested the experiment, conceived and designed the experiment, analyzed the data, and realized that additional analysis was necessary after histology did not show an effect, and wrote the manuscript. GAP was the pathologist and analyzed the data. JCB designed the experiment, provided the virus, and performed the experiment. JRP analyzed the data and wrote the manuscript. All authors approved the manuscript for publication.

\section{Acknowledgements}

The Authors would like to thank Val Hemming, Harvey B. Pollard, and Dennis McDaniel for technical advice, and Cara Olsen and Max Tran for providing statistical advice.

\section{References}

1 Tisoncik JR, Korth MJ, Simmons CP, Farrar J, Martin TR and Katze MG: Into the eye of the cytokine storm. Microbiol Mol Biol Rev 76(1): 16-32, 2012. PMID: 22390970. DOI: 10.1128/MMBR.05015-11

2 Schmolke M, Viemann D, Roth J and Ludwig S: Essential impact of NF-kappaB signaling on the H5N1 influenza A virusinduced transcriptome. J Immunol 183(8): 5180-5189, 2009. PMID: 19786538. DOI: 10.4049/jimmunol.0804198

3 DeDiego ML, Nieto-Torres JL, Regla-Nava JA, JimenezGuardeño JM, Fernandez-Delgado R, Fett C, Castano-Rodriguez $\mathrm{C}$, Perlman S and Enjuanes L: Inhibition of NF-kB-mediated inflammation in severe acute respiratory syndrome coronavirusinfected mice increases survival. J Virol 88(2): 913-924, 2014. PMID: 24198408. DOI: 10.1128/JVI.02576-13

4 Guo YR, Cao QD, Hong ZS, Tan YY, Chen SD, Jin HJ,Tan K$\mathrm{S}$, Wang D-Y and Yan Y: The origin, transmission and clinical therapies on coronavirus disease 2019 (COVID-19) outbreak an update on the status. Mil Med Res 7(1): 11, 2020. PMID: 32169119. DOI: 10.1186/s40779-020-00240-0

5 Huang C, Wang Y, Li X, Ren L, Zhao J, Hu Y, Zhang L, Fan G, Xu J, Gu X, Cheng Z, Yu T, Wei Y, Wu W, Xie X, Yin W, Li H, Liu M, Xiao Y, Gao H, Xie J, Wang G, Jiang R, Gao Z, Jin Q, Wang J and Cao B: Clinical features of patients infected with 2019 novel coronavirus in Wuhan, China. Lancet 395(10223): 497-506, 2020. PMID: 31986264. DOI: 10.1016/S0140-6736(20)30183-5

6 Yang M, Cao L, Xie M, Yu Y, Kang R, Yang L, Zhao M and Tang D: Chloroquine inhibits HMGB1 inflammatory signaling and protects mice from lethal sepsis. Biochem Pharmacol 86(3): 410418, 2013. PMID: 23707973. DOI: 10.1016/1.bcp.2013.05.013

7 Teijaro JR, Walsh KB, Long JP, Tordoff KP, Stark GV, Eisfeld AJ, Kawaoka Y, Rosen H and Oldstone M: Protection of ferrets from pulmonary injury due to H1N1 2009 influenza virus infection: immunopathology tractable by sphingosine-1phosphate 1 receptor agonist therapy. Virology 452-453: 152157, 2014. PMID: 24418500. DOI: 10/1016/j.virol.2014.01.003 
8 Yang S, Qiang L, Sample A, Shah P and He YY: NF-kB Signaling Activation Induced by Chloroquine Requires Autophagosome, p62 Protein, and c-Jun N-terminal Kinase (JNK) Signaling and Promotes Tumor Cell Resistance. J Biol Chem 292(8): 3379-3388, 2017. PMID: 28082672. DOI:10.1074/jbc.M116.756536

9 Zhang Q, Lenardo MJ and Baltimore D: 30 Years of NF-kappaB: A Blossoming of Relevance to Human Pathobiology. Cell 168(12): 37-57, 2017. PMID: 28086098. DOI: 10.1016/j.cell.2016.12.012

10 Srivastava M, Eidelman O, Zhang J, Paweletz C, Caohuy H, Yang Q, Jacobson KA, Heldman E, Huang W, Jozwik C, Pollard BS and Pollard HB: Digitoxin mimics gene therapy with CFTR and suppresses hypersecretion of IL-8 from cystic fibrosis lung epithelial cells. Proc Nat Acad Sci (USA) 101(20): 7693-7698, 2004. PMID: 15136726 . DOI: 10.1073/pnas.0402030101

11 Zeitlin PL, Diener-West M, Callahan KA, Lee S, Talbot CC, Jr., Pollard B, Boyle MP and Lechtzin N: Digitoxin for airway inflammation in cystic fibrosis: preliminary assessment of safety, pharmacokinetics, and dose finding. Ann Amer Thor Soc 14(2): 220-229, 2017. PMID: 28006108. DOI: 10.1513/AnnalsATS. 201608-649OC

12 Pollard BS, Suckow MA, Wolter WR, Starr JM, Eidelman O, Dalgard CL, Kumar P, Cattacharyya S, Srivastava M, Biswas R, Wilkerson MD, Xhang X, Yang Q and Pollard HB: Digitoxin inhibits epithelial-to-mesenchymal-transition in hereditary castration resistant prostate cancer. Front Oncol 9: 630, 2019. PMID: 31428571. DOI:10:3389/fonc.2019.00630

13 Yang Q, Soltis AR, Sukumar G, Zhang X, Caohuy H, Freedy J. Dalgard CL, Wilkerson MD, Pollard HB and Pollard BS: Gene therapy-emulating small molecule treatments in cystic fibrosis airway epithelial cells and patients. Resp Res 20(1): 290, 2019. PMID: 31864360. DOI: 10.1186/s12931-019-1214-8

14 Miller SC, Huang R, Sakamuru S, Shukla SJ, Attene-Ramos MS, Shinn P, Van Leer D, Leister W, Austin CP and Xia M: Identification of known drugs that act as inhibitors of NFkappaB signaling and their mechanism of action. Biochem Pharmacol 79(9): 1272-1280, 2010. PMID: 20067776. DOI: 10.1016/j.bcp.2009.12.021

15 Hoffman BJ and Bigger J: Digitalis and Allied Cardiac Glycosides in Goodman and Gilman's The Pharmacological Basis of Therapeutics Eighth Edition. Gilman AG, Rall TW (eds). New York: Permagon Press, 1990.

16 Ko M, Chang SY, Byun SY, Choi I, Hung A-LP, d'Orengiani D'A, Shum D, Min J-Y and Windisch MP: Screening of FDAapproved drugs using a MERS-CoV clinical isolate from South Korea identifies potential therapeutic options for COVID-19. bioRxiv, 2020. DOI: 10.1101/2020.02.25.965582

17 Cho J, Lee YJ, Kim J-H, Kim SI, Kim SS, Choi B-S and Choi J-H: Antiviral activity of digoxin and ouabain against SARSCoV-2 infection and its implication for COVID-19. Sci Rep, 10(1): 16200, 2020. PMID: 33004837. DOI: 10.1038/s41598020-72879-7

18 Mifsud EJ, Tal CMK and Hurt AC: Animal models to assess influenza antivirals. Expert Opin Drug Discov 13: 12, 11311139, 2018. PMID: 30362841. DOI: 10.1080/17460441. 2018.1540586

19 Ottolini MG, Blanco JCG, Eichelberger MC, Porter DD, Pletneva L, Richardson JY and Prince GA: The cotton rat provides a useful small-animal model for the study of influenza virus pathogenesis. J Gen Virol 86(Pt 10): 2823-2830, 2005. PMID: 16186238. DOI: 10.1099/vir.0.81145-0
20 Kalb DM, Adikari SH, Hong-Geller E and Werner JH: Singlecell correlations of mRNA and protein content in a human monocytic cell line after LPS stimulation. PLoS One 14(4): e0215602, 2019. PMID: 31002726. DOI: 10.1371/journal. ponme. 0215602

21 De Filippo K, Henderson RB, Laschinger M and Hogg N: Neutrophil chemokines KC and Macrophage-Inflammatory Protein-2 are newly synthesized by tissue macrophages using distinct TLR signaling pathways. J Immunol 180: 4308-4315, 2008. PMID: 18322244. DOI: 10.4049/jimmunol.180.6.4308

22 Perrier D, Mayersohn M and Marcus FI: Clinical pharmacology of digitoxin. Clin Pharmacokinet 2: 292-311, 1977. PMID: 902449. DOI: 10.2165/00003088-197702040-00005

23 Nair AB and Jacob S: A simple practice guide for dose conversion between animals and human. J Basic Clin Pharmacy 7: 27-31, 2016. PMID: 27057123. DOI: 10.4103/0976-0105.177703

24 Prince GA, Curtis SJ, Yim KC and Porter DD: Vaccine-enhanced respiratory syncytial virus disease in cotton rats following immunization with Lot 100 or a newly prepared reference vaccine. J Gen Virol 82(Pt 12): 2881-2888, 2001. PMID: 11714962. DOI: $10.1099 / 0022-1317-82-12-2881$

25 Mah AY and Cooper MA: Metabolic regulation of natural killer cell IFN- $\gamma$ production. Crit Rev Immunol 36(2): 131-147, 2016. PMID: 27910764. DOI: 10.1615/CritRevImmunol.2016017387

26 Mills PR, Davies RJ and Devalia JL: Airway epithelial cells, cytokines, and pollutants. Am J Respir Crit Care Med 160(5 Pt 2): S38-S43, 1999. PMID: 10556168. DOI: 10.1164/ajrccm.160. supplement_1.11

27 Liu T, Zhang L, Joo D and Sun SC: NF-kB signaling in inflammation. Signal Transduct Target Ther 2: 17023, 2017. PMID: 29158945. DOI: 10.1038/sigtrans.2017.23

28 Hol J, Wilhelmsen L and Haraldsen G: The murine Il-8 homologues KC, MIP-2 and LIX are found in endothelial cytoplasmic granules but not Weibel-palade bodies. J Leuk Biol 87(3): 501-508, 2009. PMID: 20007247. DOI: 10.1189/jlb.0809532

29 Deshmane SL, Kremlev S, Amini S and Sawaya BE: Monocyote chemoattracrant protein-1 (MCP-1): an overview. J Interferon Cytokine Res 29(6), 2009. PMID: 19441883. DOI: 10.1089/jir.2008.0

30 Kumar N, Xin ZT, Liang Y, Ly H and Liang Y: NF-kappaB signaling differentially regulates influenza virus RNA synthesis. J Virol 82(20): 9880-9889, 2008. PMID: 18701591. DOI: 10.1128/JVI.00909-08

31 Nimmerjahn F, Dudziak D, Dirmeier U, Hobom G, Riedel A, Schlee M, Staudt LM, Rosenwald A, Behrends U, Bornkamm GW and Mautner J: Active NF-kappaB signalling is a prerequisite for influenza virus infection. J Gen Virol 85(Pt 8): 2347-2356, 2004. PMID: 15269376. DOI: 10.1099/vir.0.79958-0

32 Wurzer WJ, Ehrhardt C, Pleschka S, Berberich-Siebelt F, Wolff T, Walczak H, Planz O and Ludwig S: NF-kappaB-dependent induction of tumor necrosis factor-related apoptosis-inducing ligand (TRAIL) and Fas/FasL is crucial for efficient influenza virus propagation. The J Biol Chem 279(30): 30931-30937, 2004. PMID: 14143063 . DOI: 10.1074/jbc.M403258200

33 Dam S, Kracht M, Pleschka S and Schmitz ML: The influenza A virus genotype determines the antiviral function of NF-kB. J Virol 90(17): 7980-7990, 2016. PMID: 27356900. DOI: 10.1128/JVI. 00946-16

34 Yan H, Wang H, Ma L, Ma X, Yin J, Wu S, Huang H and Li Y: Cirsimaritin inhibits influenza $\mathrm{A}$ virus replication by 
downregulating the NF-kB signal transduction pathway. Virol J 15(1): 88, 2018. PMID: 29783993. DOI:10.1186/s12985-0180995-60

35 Liu B, Bao L, Wang L, Li F, Wen M, Li H, Deng W, Zhang X and $\mathrm{Cao} \mathrm{B}$ : Anti-IFN- $\gamma$ therapy alleviates acute lung injury induced by severe influenza A (H1N1) pdm09 infection in mice. J Microbiol Immunol Infect 12: S1684-11829(18)30438-9, 2019. PMID: 31780358. DOI: 10.1016/j.jmii.2019.07.009

36 Sica A, Dorman L, Viggiano V, Cippitelli M, Ghosh P, Rice N and Young HA: Interaction of NF-kappaB and NFAT with the interferon-gamma promoter. J Biol Chem 272(48): 30412-30420, 1997. PMID: 93744532. DOI: $10.1074 / \mathrm{jbc} .272 .48 .30412$

37 Yang QF, Dalgard CL, Eidelman O, Jozwik C, Pollard BS, Srivastava M and Pollard HB: Digitoxin induces apoptosis in cancer cells by inhibiting nuclear factor of activated T-cellsdriven c-MYC expression. J Carcinogenesis 12: 8, 2013. PMID: 32858296. DOI: $10.4103 / 1477-3163.112268$

38 Ichinohe T, Lee HK, Ogura Y, Flavell R and Iwasaki A: Inflammasome recognition of influenza virus is essential for adaptive immune responses. J Exp Med 206(1): 79-87, 2009. PMID: 19139171. DOI: 10.1084/jem.20081667

39 Sichelstiel A, Yadava K, Trompette A, Salami O, Iwakura Y, Nicod LP and Marsland BJ: Targeting IL- $1 \beta$ and IL-17A driven inflammation during influenza-induced exacerbations of chronic lung inflammation. PloS one 9(2): e98440, 2014. PMID: 24918427. DOI: 10.1371/journal.pone.0098440

40 Jolly L, Stavrou A, Vanderstoken G, Meliopoulos VA, Habgood A, Tatler AL, Porte J, Knox A, Weinreb P, Violette S, Hussell T, Kolb M, Stampfli MR, Schultz-Cherry $S$ and Jenkins G: Influenza promotes collagen deposition via $\alpha v \beta 6$ integrinmediated transforming growth factor $\beta$ activation. J Biol Chem 289(51): 35246-35263, 2014. PMID: 25339175. DOI: 10.1074/jbc.M114.582262

41 Yang Q, Huang W, Jozwik C, Lin Y, Glasman M, Caohuy H, Sruvastava M, Esposito D, Gillette W, Hartley J and Pollard HB: Cardiac glycosides inhibit TNF-alpha/NF-kappaB signaling by blocking recruitment of TNF receptor-associated death domain to the TNF receptor. Proc Nat Acad Sci (USA) 102(27): 96319636, 2005. PMID: 15983368. DOI: 10.1073/pnas.0504097102
42 Wang H, Cebotaru L, Lee HW, Yang Q, Pollard BS, Pollard HB and Guggino WB: CFTR controls the activity of NF-kappaB by enhancing the degradation of TRADD. Cell Physiol and Biochem 40(5): 1063-1078, 2016. PMID: 27960153. DOI: $10.1159 / 000453162$

43 Amarelle L and Lecuona E: The antiviral effects of Na,KATPase inhibition: A minireview. Int J Mol Sci 19(8), 2018. PMID: 30042322. DOI: 10.3390/ijms19072154

44 Burkard C, Verheije MH, Haagmans BL, van Kuppeveld FJ, Rottier PJ, Bosch BJ and de Haan CAM: ATP1A1-mediated Src signaling inhibits coronavirus entry into host cells. J Virol 89(8): 4434-4448, 2015. PMID: 25653449. DOI: 10.1128/JVI.0327414

45 Wei T, Wang H, Wu X, Lu Y, Guan S, Dong F, Dong C, Zhu G, $\mathrm{B}$ ao $\mathrm{Y}$, Zhang $\mathrm{J}$, Wang $\mathrm{G}$ and $\mathrm{Li} \mathrm{H}$ : in silico screening of potential spike glycoprotein inhibitors of SARS-CoV-2 with drug repurposing strategy. Chin J Integr Med 26(9): 663-669, 2020. PMID: 32740825. DOI: 10.1007/s11655-020-3427-6

46 Senathilake KS, Samarakoon S and Tennekoon K: Virtual screening of inhibitors against spike glycoprotein of SARS-CoV2: a drug repurposing approach. Preprints, 2020. DOI: 10.20944/preprints202003.0042.v2

47 Farag A, Wang P, Boys IN, Eitson JL, Ohlson MB, Fan W, McDougal MB, Ahmed M, Schoggins JW and Sadek H: Identification of atovaquone, ouabain and mebendazole as FDA approved drugs targeting SARS-CoV-2. ChemRxiv, 2020. DOI: 10.26434/chemrxiv.12003930

48 Aanouz I, Belhassan A, El-Khatabi K, Lakhlifi T, El-Ldrissi M and Bouachrine M: Moroccan medicinal plants as inhibitors against SARS-CoV-2 main protease: Computational investigations. J Biomol Struct Dyn 6: 1-9, 2020. PMID: 32306860. DOI: 10.1080/07391102.2020.1758790

Received September 18, 2020

Revised October 17, 2020

Accepted October 19, 2020 